Bangladesh J. Plant Taxon. 28(1): 257-270, 2021 (June)

(C) 2021 Bangladesh Association of Plant Taxonomists

https://doi.org/10.3329/bjpt.v28i1.54221

\title{
MOSSES OF DAQAHLIA PROVINCE WITH ONE NEW RECORD FOR AFRICA AND THREE NEW RECORDS FOR EGYPT
}

\author{
Usama Y. Abou-Salama ${ }^{1}$, Gamal M.A. Lashin, Ekram M. Abdelhaliem \\ AND GEHAD A.A. HAMOUdA* \\ Department of Botany and Microbiology, Faculty of Science, Zagazig University, Egypt
}

Keywords: Mosses; New records; Egypt.

\begin{abstract}
Thirty six moss species were recorded from Daqahlia province, Nile Delta. Weissia perligulata Flow. (Pottiaceae) was new record to Afr1. In addition, Hyophila involute (Hook.) Jaeg., (Pottiaceae), Ptychostomum arcticum (R. Brown) J. R. Spence ex Holyoak $\&$ N. Pederson and P. cyclophyllum (Schwagr) J. R. Spence (Bryaceae) were new records for Egypt. Fifteen species were new to Nile delta. This raised the number of identified moss taxa recorded from Egypt up to 192 taxa, from Nile delta 51 taxa and Daqahlia province 39 taxa. Data on the up-to-date classification, habitats, voucher specimens and distribution of the enumerated species and the descriptions of the new records including the photos have been provided.
\end{abstract}

\section{Introduction}

Number of moss taxa now from Egypt has been quietly increased in the last decade into 188 taxa belonging to 59 genera, 17 families and 10 orders (El-Saadawi et al., 2013 a,b; Ibrahim et al., 2013; Hassan et al., 2017; El-Sakaty et al., 2018; Khalil and Farag, 2018; Taha, 2020). The distribution of the 188 moss taxa in the 11 surveyed phytogeographical territories of Egypt (out of 13 territories) showed that Southern Sinai, Western Mediterranean Costal Land, Cairo, and Isthmic Desert of Egypt are the richest territories regarding the number of recorded moss taxa (ElSaadawi et al., 2015).

A total of 59 genera and 188 taxa are known from this country (El-Saadawi et al., 2015; Hassan et al., 2017; El-Sakaty et al., 2018; Khalil and Farag, 2018).

The last study on the Bryoflora of Daqahlia province was accomplished more than 34 years before by El-Saadawi et al., (1986) as a part of Nile delta moss flora. The present study was aimed to explore the current status of the bryoflora of Daqahlia province, Nile Delta and Egypt.

\section{Materials and Methods}

Daqahlia province is located at the north-east of Nile Delta and bounded by El-Sharkia province on the east, El-Gharbia and Kafr El-Sheikh provinces on the west, Domietta province on the north-east, El-Qalyobia province on the south and the Mediterranean coast on the north. It is located in between longitudes $30.5^{\circ} \mathrm{N}$ and $31.5^{\circ} \mathrm{N}$, and latitudes $30^{\circ} \mathrm{E}$ and $32^{\circ} \mathrm{E}$ (Figs. 1-2).

Daqahlia has a mild climate that tends to be warm in winter with little rain, which increases in the coast, and is hot in summer, where the average annual temperature ranges between 14 and $28^{\circ} \mathrm{C}$.

*Corresponding author. E-mail: gahamouda@gmail.com

${ }^{1}$ Department of Botany, Faculty of Science, Ain Shams University, Egypt. 
Two hundred and sixty four moss samples were collected from 11 districts of Daqhlia province during October 2017 to December 2019, covering all seasons, viz. winter (110 samples), spring ( 88 samples), autumn (39 samples) and summer (27 samples). All were numbered and kept in CAIA. Identification of the samples were confirmed by comparisons with authentic specimens kept in CAIA, relevant literatures on the moss flora of Egypt and with reference texts of some standard moss floras (Flowers, 1973; Refai, 1985; Lashin, 1990; Ibrahim, 2006; Taha, 2010, 2014; Hamouda, 2016).

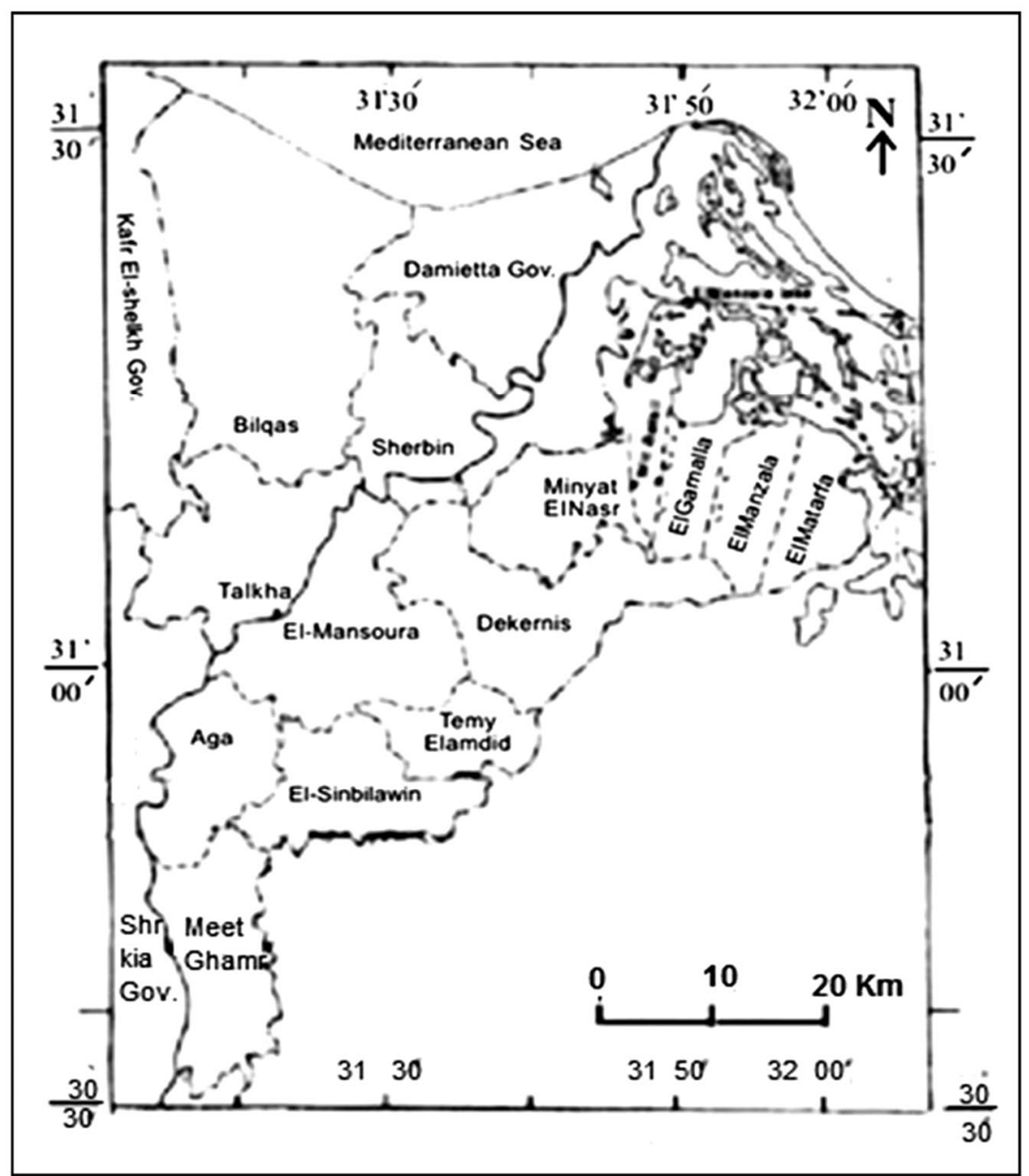

Fig.1. Map showing the location of the districts of El Daqahlia province (after Mandour, 2013). 


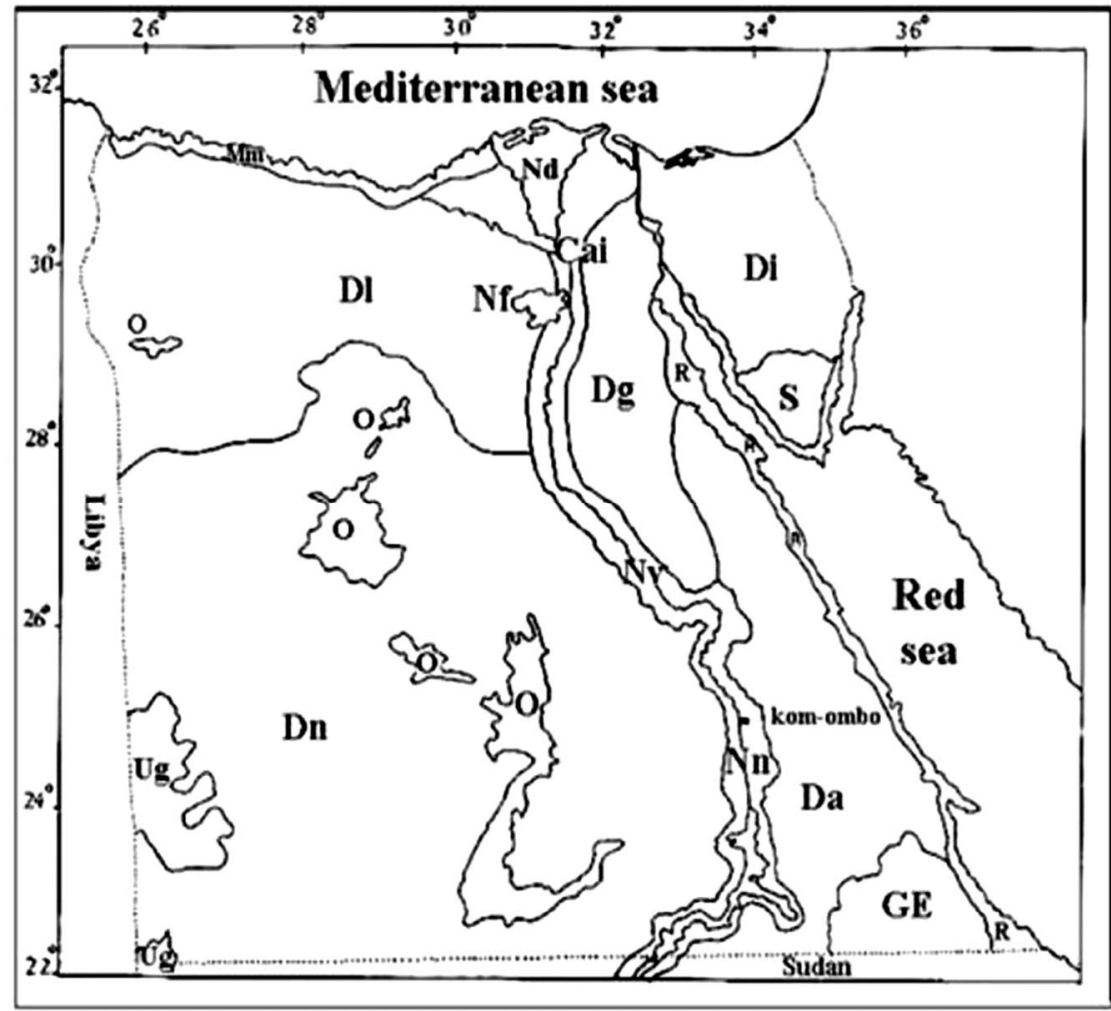

Fig. 2. Map showing phytogeographical territories in Egypt (After El-Saadawi et al., 2003). Cai: Cairo area; Da: Arabian Desert; Dg: Galala Desert; Di: Isthmic Desert; Dl: Libyan Desert; Dn: Nubian Desert; GE: Gebel Elba; Mm: Western Mediterranean coastal land (Mareotic sector); Nd: Nile Delta; Nf: Nile Faiyum; Nn: Nile Nubia, from Kom-Omho southwards to Egyptian boundaries with the Sudan including the areas now inundated by the waters of Lake Naser since 1965; Nv: Nile Valley, from Cairo-Giza to Kom-Ombo; On \& Ol: Oases of the Nubian and Libyan Deserts; R: Red Sea coastal plains; S: Southern Sinai massive (Sinai proper i.e. relatively high mountains, south of Isthmic desert).

\section{Results and Discussion}

The investigation of 264 samples revealed the occurrence of 36 moss species belonging to 19 genera under six families and four orders in Daqahlia province. By adding three moss species, namely, Fissidens viridulus (Sw.) Wshlenb. (Fissidentaceae), Brum radiculosum Brid. (Bryaceae) and Pohlia melanodon (Brid.) A.J. Shaw (Mniaceae), recorded previously by El-Saadawi et al. (1986) but not recorded by the present study, the number of moss elements of Daqahlia province was increased to 39 moss species under 20 genera. Pottiaceae is the largest family (19 species, 10 genera), followed by Bryaceae (11 species, three genera) and Funariaceae (four species, three genera), Fissidentaceae (three species, one genus), and Mniaceae and Baratramiaceae (one species, one genus each).

Three species, namely, Hyophila involute (Hook.) Jaeg., Ptychostomum arcticum (R. Brown) J.R. Spence ex Holyoak \& N. Pederson, and P. cyclophyllum (Schwagr) J.R. Spence found in Daqahlia province during this study, are the new records for the bryoflora of Egypt, whereas Weissia perligulata Flow found in this province is new to Africa. 
Five out of 36 species (about 13.9\%), namely Tortula inermis, Entothodon muehlenbergii, Funaria hygrometica, Physcomitrium niloticum and P. pyriforme are fruit yielding, six species (about 16.7\%), namely Barbula indica, Bryoerythrophyllum recurvirostrum, Didymodon luridus, Gymnostomum aeruginosum, Syntrichia fragilis and Trichostomum brachydontium are female and one species (about 2.8\%), namely Fissidens bryoides, is monoecious without fruit, while the remaining 24 species (about 66.7\%) are sterile. Seven species (about 19.4\%), viz. Imbribryum alpinum and Syntrichia fragilis (with axillary gemmae); Bryum argenteum, B. dichotomum, B. gemmiparum and Trichostomum brachydontium (with rhizoidal gemmae); Philonotis hastata (with bulbils) are recognized as reproducing by asexual propagules.

All of the 39 moss species are taxonomically listed, and their voucher specimen(s), locality(ies), habitats, distribution in Egypt (El-Saadawi et al., 2003), Afr1 (Ros et al., 2013) and the world (Wijk et al, 1959-1969) are given with descriptions and photos of new records. The recorded taxa are briefly described below.

Order: Fissidentales, Family: Fissidentaceae

Genus: Fissidens Hedw.

1. F. arnoldii R. Ruthe

Locality: Meet-Ghamr. Voucher specimen: GH 175. Habitat: On red brick walls of water canal, exposed to light. Distribution in Egypt: Di, S, GE. Distribution in Afr1: ALG. Distribution in the World: Afr1, As5, Eur, Am1.

2. F. Bryoides Hedw.

Localities: Meet-Ghamr, Aga, Mainiat El-Nasr. Voucher specimens: GH 173, GH 266, GH 380. Habitats: On red brick walls of water canal \& on lime stone of water wheel, in shade. Distribution in Egypt: Cai, Dg, Di, Distribution in Afr1: TUN. Distribution in the World: Afr1, Eur.

3. F. viridulus (Sw.) Wshlenb.

Syn. F. Bryoides Hedw. Spp. viridulus (Sw.) Kindb. Previously recorded, not collected in the present work. Distribution in Egypt: Nn, Nv, Nf, Cai, Dg, GE, Mm. Distribution in Afr1: CN, ALG, MOR, TUN. Distribution in the World: Afr1, As5, Eur.

Order: Pottiales, Family: Pottiaceae

Genus: Barbula Hedw.

4. B. bolleana (Mull, Hal.) Broth.

Localities: Meet-Ghamr, El-Mansoura, Dekerns. Voucher specimens: GH 179, GH 164, GH 345, GH 364. Habitats: On red brick walls of water basin and water wheel, in semi-shade. Distribution in Egypt: Nn, Nv, Nf. Cai, S, Mm. Distribution in Afr1: LBY, CHA, ALG, MOR, TYN. Distribution in the World: Afr1, Afr2, Afr3, Afr4, As2, As5, Eur, Am1, Am2, Am3, Austr1.

5. B. convoluta Hedw.

Locality: Aga. Voucher specimen: GH 297. Habitat: On red brick walls of water basin, in semi-shade. Distribution in Egypt: Nn, Dg, S. Distribution in Afr1: LBY, CN, ALG, MOR, TUN. Distribution in the World: Afr1, As1, As2, As5, Eur, Am1, Am2, Austr2.

6. B. indica (Hook.) Spreng.

Locality: Meet-Ghamr. Voucher specimen: GH 185. Habitat: On red brick walls of water basin, exposed to light. Distribution in Egypt: Nv, Cai. Distribution in Afr1: EGY. Distribution in the World: Afr1, Afr2, Afr3, Afr4, As2, As3, As4, As5, Eur, Am1, Am2, Am3, Am4, Am5, Austr1. 
7. B. unguiculata Hedw.

Localities: Meet-Ghamr, Mainiat El-Nasr, Al-Manzalah. Voucher specimens: GH 172, GH 384, GH 390, GH 386, GH 389. Habitats: On red brick walls of waterway, water basin, a house, in semi-shade and exposed to light. Distribution in Egypt: Nv, Nf, Cai, Dg, Mm. Distribution in Afr1: LBY, CHA, ALG, MOR, TUN. Distribution in the World: Afr1, Afr2, Afr3, Afr4, As2, As5, Eur, Am1, Am2, Am3, Austr1.

Genus: Bryoerythrophyllum Chen.

8. B. recurvirostrum (Hedw.) Chen.

Locality: Meet-Ghamr. Voucher specimens: GH181, GH 162. Habitats: On red brick walls of water basin and water canal, in semi-shade. Distribution in Egypt: Di. Distribution in Afr 1: CHA, ALG, MOR, TUN. Distribution in the World: Afr1, Afr2, Afr3, Afr4, As1, As2, As3, As4, As5, Eur, Am1, Am2, Austr1, Oc.

Genus: Didymodon Hedw.

9. D. luridus Hornsch.

Locality: El-Mansoura. Voucher specimen: GH 283. Habitat: On red brick walls of water basin, in shade. Distribution in Egypt: Nf, Cai, Dg, S, Mm. Distribution in Afr1: LBY, CHA, CN, ALG, MOR, TUN. Distribution in the World: Afr1, Afr2, As1, As2, As5, Eur, Am2, Am3.

10. D. tophaceus (Brid.) Lisa

Localities: Meet-Ghamr, El-Mansoura. Voucher specimens: GH 222, GH 347. Habitats: On red brick walls of water basin and water wheel, in semi-shade. Distribution in Egypt: Nn, Nv, Nf, Cai, Dg, S, GE, O, Mm. Distribution in Afr1: LBY, CHA, CN, ALG, MOR, TUN. Distribution in the World: Afr1, Afr2, As1, As3, As5, Eur, Am1, Am2, Am4.

11. D. vinealis (Brid.) R. H. Zander

Localities: Aga, El-Mansoura, Dekerns. Voucher specimens: GH 264, GH 345, GH 364. Habitats: On red brick walls of water wheel and water well, in shade. Distribution in Egypt: Di, S, O. Distribution in Afr1: LBY, CN, ALG, MOR, MLI, TUN. Distribution in the World: Afr1, As1, As2, As3, As5, Eur, Am1, Am2, Am4, Am6.

Genus: Gymnostomum Nees \& Hornsch

12. G. aeruginosum $\mathrm{Sm}$.

Locality: Aga. Voucher specimen: GH 279. Habitat: On red brick walls of water basin, in shade. Distribution in Egypt: Nf, Cai, S, O. Distribution in Afr1: CHA, CN, ALG, MOR, MLI, TUN. Distribution in the World: Afr1, Afr2, Afr3, Afr4, As1, As2, As3, As5, Eur, Am1, Am2, Am3, Am6, Austr1, Austr2, Oc.

13. G. calcareum Nees \& Hornsch.

Locality: Meet-Ghamr. Voucher specimen: GH 233. Habitat: On red brick walls of water canal, exposed to light. Distribution in Egypt:Nv, Nf, Dg, S, GE, Mm. Distribution in Afr 1: LBY, CHA, CN, ALG, MOR, TUN. Distribution in the World: Afr1, Afr2, Afr3, Afr4, As1, As2, As3, As5, Eur, Am1, Am2, Am6, Austr1, Austr2, Oc.

Genus: Hyophila Brid.

14. H. involute (Hook.) Jaeg.

(Plate 1)

Plants sterile, olive green, up to $5.5 \mathrm{~mm}$ high. Stem branched or unbranched, central strand poorly developed, sclerodermis well differentiated. Leaves erecto-patent to spreading when moist, oval to oblong, 2.5 to $2.9 \mathrm{~mm}$ long, 1 to 1.2 wide, larger leaves at stem apex; apex 
narrowly acute; margin plane, irregularly notched or irregularly toothed; costa ending below apex by 2-3 cells, superficial cells quadrate to elongated, irregular, oval in cross section, with \pm two equal stereid bands, with 6 guides, dorsal superficial cells slightly papillose; upper lamina cells quadrate, pentagonal, rounded, basal lamina cells rounded, quadrate to subquadrate.

Localities: Meet-Ghamr, Mainiat El-Nasr. Habitats: On red brick walls of water canal and water wheel, in shade. Distribution in Egypt: New record. Distribution in Afr1: Egypt only. Distribution in the World: Afr1, As5, Eur, Am3. Specimens examined: Meet-Ghamr: Bashla village, 20.4.2018, Gehad Hamouda, GH 219, Mainiat El-Nasr: Draksah village, 1.11.2019, Gehad Hamouda, GH 373, GH 379 (CAIA)
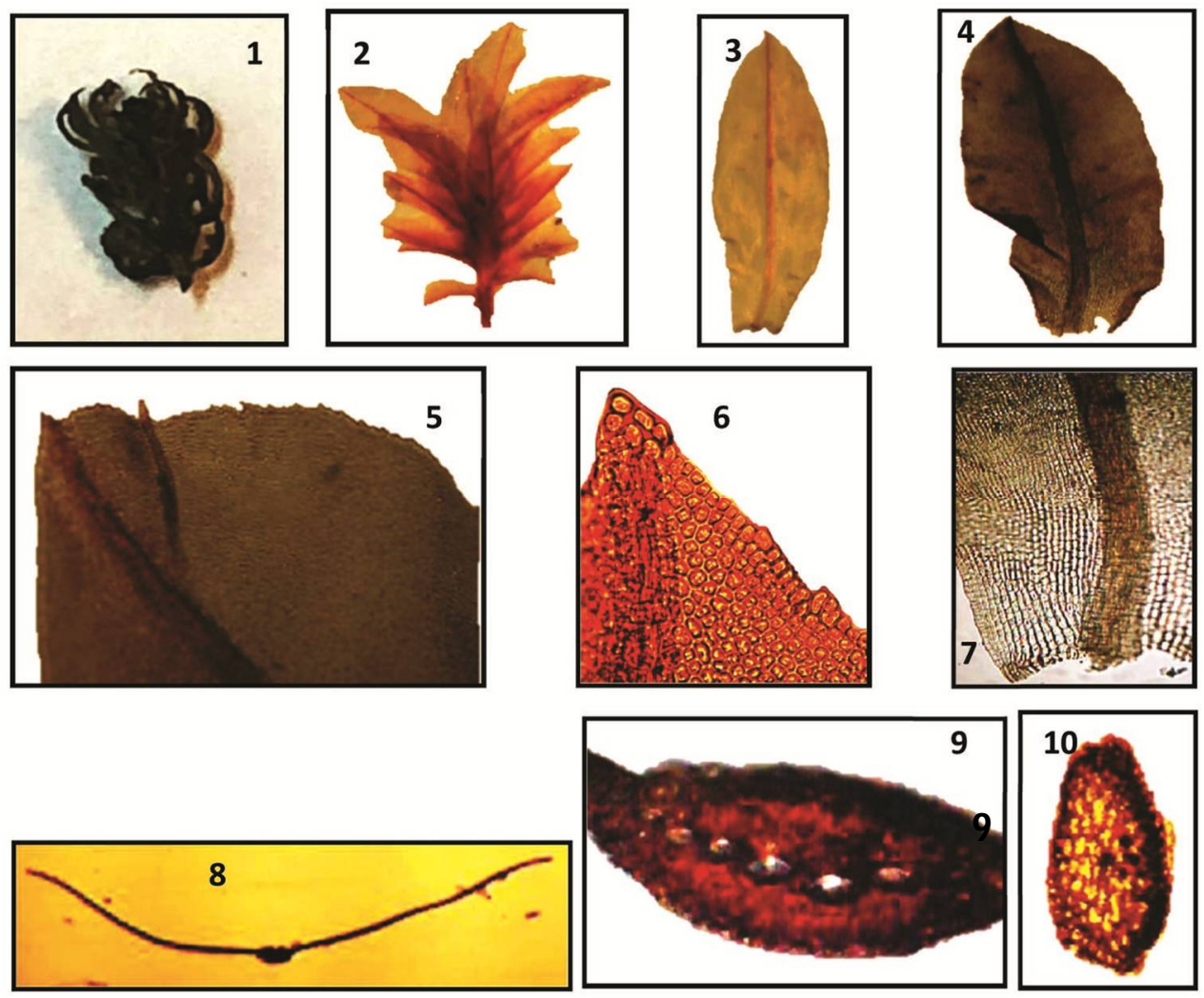

Plate 1. Hyophila involuta (Hook.) Jaeg.; 1- Dry plant (X6), 2- Fresh plant (X9), 3 \& 4- Leaves (X18,X19), 5- Leaf apex (X83), 6- Upper leaf cells (X235), 7- Basel leaf cells (X93), 8 \& 9 - T.S. of leaf (X66, X712), 10- T.S. of stem (X68).

Genus: Oxystegus (Hook. \& Taylor) A.J.E. Sm.

15. O. tenuirostris (Hook. \& Taylor) A.J.E. Sm.

Locality: El-Mansoura. Voucher specimens: GH 289, GH 344, GH 351. Habitats: On red brick walls of water canal and water well, in semi-shade and exposed to light. Distribution in Egypt: Nv. Distribution in Afr1: ALG, MOR. Distribution in the World: Afr1, As1, As2, As4, As5, Eur, Am1, Am2, Am4, Am5. 
Genus: Splachnobryum Müll. Hal.

16. S. obtusum (brid.) Müll. Hal.

Locality: Talkha. Voucher specimen: GH 337. Habitat: On red brick walls of water basin, in shade. Distribution in Egypt: recorded previously in Nd only. Distribution in Afr1: CHA. Distribution in the World: Afr1, Afr2, Afr3, Afr4, As2, As4, Eur, Am1, Am2, Austr1.

Genus: Syntrichia Brid.

17. S. fragilis (Taylor) Ochyra

Locality: Meet-Ghamr. Voucher specimen: GH 183. Habitat: On red brick walls of water basin, in semi-shade. Distribution in Egypt: S. Distribution in Afr1: CN, ALG, MOR, TUN. Distribution in the World: Afr1, Afr2, Afr3, Afr4, As3, As5, Eur, Am1, Am2, Am3, Am4.

Genus: Tortula Hedw.

18. T. inermis (Brid.) Mont.

Locality: El-Mansoura. Voucher specimen: GH 281. Habitat: On red brick walls of water basin, in shade. Distribution in Egypt: Di, S. Distribution in Afr1: LBY, CHA, CN, ALG, MOR, TUN. Distribution in the World: Afr1, As1, As2, As3, As5, Eur, Am1, Am2.

19. T. muralis Hedw.

Locality: Belqas. Voucher specimen: GH 416. Habitat: On red brick walls of a house, in semishade. Distribution in Egypt: Cai, Dg, Di, Mm. Distribution in Afr1: LBY, ALG, MOR, TUN. Distribution in the World: Afr1, Afr4, As2, As5, Eur, Am1, Am6.

\section{Genus: Trichostomum Bruch}

20. T. brachydontium Bruch

Localities: Meet-Ghamr, El-Mansoura. Voucher specimens: GH 241, GH 244, GH 355. Habitats: On red brick walls of water basin, on lime stone wall of water well, in semi-shade. Distribution in Egypt: Di. Distribution in Afr1: ALG, MOR, TUN. Distribution in the World: Afr1, Afr2, Afr3, Afr4, As1, As2, As3, As4, As5, Eur, Am1, Am2, Am3, Am4, Am5, Am6.

\section{T. crispulum Bruch}

Localities: Aga, Mainiat El-Nasr. Voucher specimens: GH 208, GH 383. Habitat: On red brick walls of water wheel, in shade. Distribution in Egypt: Di, S, Mm. Distribution in Afr 1: LBY, CHA, ALG, MOR, TUN. Distribution in the World: Afr1, Afr2, Afr3, Afr4, As1, As2, As5, Eur, Am1, Am2.

Genus: Weissia Hedw.

22. W. perligulata Flow.

(Plate 2)

Plants sterile, green to olive green above, yellowish brown to brown below, up to $4.5 \mathrm{~mm}$ high. Stem usually unbranched, central strand poorly developed, sclerodermis poorly differentiated. Leaves erecto-patent to patent when moist, concave, ovate to oblong, with \pm decurrent base, 1.5 to $1.7 \mathrm{~mm}$ long, 0.5 to $0.6 \mathrm{~mm}$ wide; apex rounded; margin plane, strongly papillose above, entire below; costa percurrent, superficial cells oblong, semicircular in cross section, with two unequal stereid bands usually ventral one smaller, with 4 guides; upper lamina cells quadrate, rounded, papillose, basal lamina cells elongate to short rectangular.

Localities: Meet-Ghamr, Talkha. Habitat: On red brick walls of water canal, in semi-shade. Distribution in Egypt: New record. Distribution in Afr1: Egypt only (new record to Afr1) Distribution in the World: Afr1, Am3. Specimens examined: Meet-Ghamr: Bashla village, 23.11.2018, Gehad Hamouda, GH 226, Talkha: On the high way, 25.12.2019, Gehad Hamouda, GH 401(CAIA). 
Order: Funariales, Family: Funariaceae

Genus: Entosthodon Schwägr.

\section{E. muehlenbergii (Turner) Fife}

Localities: Meet-Ghamr, Belqas, El-Sinblawin, Talkha. Voucher specimens: GH 300, GH 191, GH 416, GH 366, GH 367. Habitats: On red brick walls of a house, lime stone wall of waterway, in semi-shade and exposed to light. Distribution in Egypt: Cai, S, GE. Distribution in Afr1: LBY, CN, ALG, MOR, TUN. Distribution in the World: Afr1, Afr2, As5, Eur, Am1, Am2.
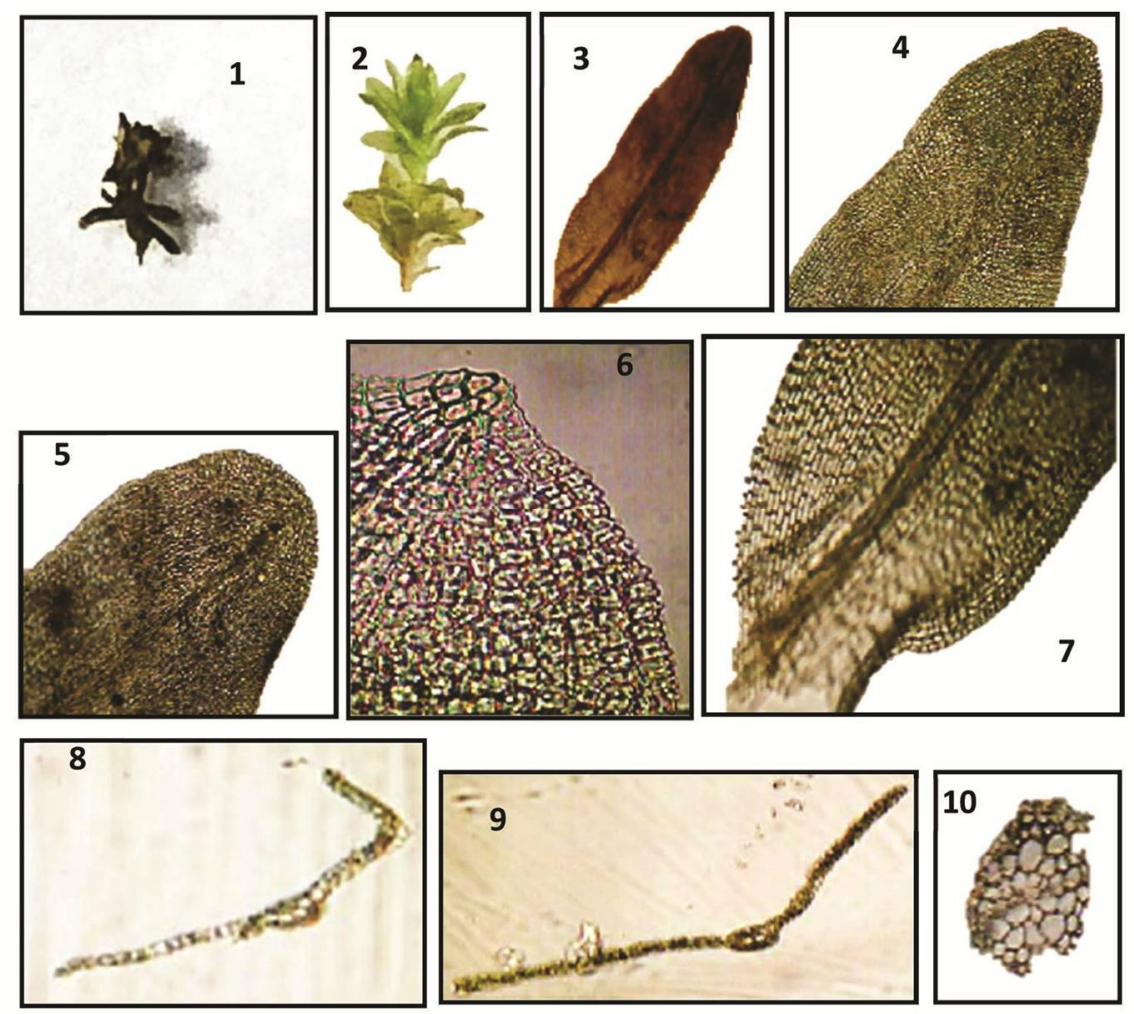

Plate 2. Weissia perligulata Flow.; 1- Dry plant (X4.4), 2- Fresh plant (X6), 3- Leaf (X33), 4 \& 5- Leaf apices (X110, X137), 6- Upper leaf cells (X270), 7- Basal leaf cells (X140), 8 \& 9 T.S. of leaf (X140, X133), 10- T.S. of stem (X135).

\section{Genus: Funaria Hedw.}

\section{F. hygrometrica Hedw.}

Localities: El-Mansoura, Talkha, Belqas. Voucher specimens: GH 299, GH 282, GH 399, GH 401, GH 404, GH 406. Habitats: On red brick walls of water canal, on clay of cultivated land, on lime stone wall of waterway, in semi-shade. Distribution in Egypt: Nn, Nv, Nf, Cai, Dg, Di, S, O, Mm. Distribution in Afr1: LBY, CHA, CN, ALG, MOR, TUN. Distribution in the World: Afr1, Afr2, Afr3, Afr4, As1, As2, As3, As4, As5, Eur, Am1, Am2, Am3, Am4, Am5, Am6, Austr1, Austr2, Oc. 
Genus: Physcomitrium (Brid.) Brid.

25. P. niloticum (Delile) Müll. Hal.

Localities: El-Mansoura, Talkha. Voucher specimens: GH 296, GH 394. Habitat(s): On clay of water basin pipe, in semi-shade. Distribution in Egypt: Nv, Nf, Cai, Dg, GE. Distribution in Afr1: Egypt only. Distribution in the World: Afr1.

26. P. pyriforme (Hedw.) Bruch \& Schimp.

Locality: Belqas. Voucher specimens: GH 409, GH 411. Habitat(s): On red brick walls of water basin, on lime stone wall of waterway, in semi-shade. Distribution in Egypt: Nn, Cai, Dg. Distribution in Afr1: CH, MOR. Distribution in the World: Afr1, As5, Eur, Am3.

Order: Bryales, Family: Bryaceae

Genus: Bryum Hedw.

27. B. argenteum Hedw.

Localities: El-Mansoura, Talkha. Voucher specimens: GH 333, GH 288. Habitat: On red brick walls of water canal, in semi-shade. Distribution in Egypt: Cai, Dg, Di, S, O, Mm. Distribution in Afr1: CHA, CN, ALG, MOR, TUN. Distribution in the World: Afr1, Afr2, Afr3, Afr4, As1, As5, Eur, Am1, Am6, Austr1, Austr2.

28. B. dichotomum Hedw.

Localities: Meet-Ghamr, El-Sinblawin, Sherbeen. Voucher specimens: GH 307, GH 368, GH 239. Habitat: On red brick walls of water canal, in semi-shade. Distribution in Egypt: Nv, Nf, Cai, Dg, Di, S, O, Mm. Distribution in Afr1: LBY, CHA, CN, ALG, MOR, TUN. Distribution in the World: Afr1, As1, As4, As5, Eur, Am2, Austr2.

29. B. gemmiparum De. Not.

Localities: Meet-Ghamr, El-Mansoura. Voucher specimens: GH 287, GH 230. Habitats: On red brick walls of water basin, on clay of water canal, in shade. Distribution in Egypt: Nf, Cai, S, O, Mm. Distribution in Afr1: CHA, ALG, MOR. Distribution in the World: Afr1, Afr2, Afr3, Afr4, As1, As2, As3, As4,As5, Eur, Am1, Am2, Am3, Am4, Am5, Am6, Austr1, Austr2.

30. B. kunzei Hornsch.

Localities: Meet-Ghamr, Aga, Al-Manzalah. Voucher specimens: GH 187, GH 390, GH 230, GH 255. Habitat: On red brick walls of water basin, in semi-shade. Distribution in Egypt: Cai, Mm. Distribution in Afr1: CHA, ALG, MOR. Distribution in the World: Afr1, As5.

31. B. radiculosum Brid.

Syn. B. murorum (Schimp.) Berk. Previously recorded, not collected in the present work. Distribution in Egypt: Cai, Di, S, O, Mm. Distribution in Afr1: CN, ALG, MOR, TUN. Distribution in the World: Afr1, Eur, As5.

32. B. subapiculatum Hampe

Locality: Belqas. Voucher specimen: GH 410. Habitat: On lime stone walls of waterway, exposed to light. Distribution in Egypt: Nv, Cai, S, O. Distribution in Afr1: CN. Distribution in the World: Afr1, As1, As3, As5, Eur, Am5, Austr1, Austr2.

Genus: Imbribryum N. Pederson

33. I. alpinum (Huds. Ex With.) N. Pederson

Locality: El-Mansoura. Voucher specimen: GH 347. Habitat: On red brick walls of water wheel, in semi-shade. Asexual propagules: Axillary gemmae. Distribution in Egypt: Nn, Nf, 
Cai, S.Distribution in Afr1: CN, ALG, MOR, TUN. Distribution in the World: Afr1, Afr2, Afr3, Afr4, As1, As2, As3, As5, Eur, Am1.

\section{Genus: Ptychostomum Hornsch.}

34. P. archangelicum (Beusch \& Schimp.) J. R. Spence

Localities: Meet-Ghamr, Aga. Voucher specimens: GH 257, GH 235. Habitat: On red brick walls of water canal, in semi-shade. Distribution in Egypt: S, O. Distribution in Afr1: ALG, MOR. Distribution in the World: Afr1, As5, Eur, Am6.

35. P. arcticum (R. Brown) J. R. Spence ex Holyoak \& N. Pederson

(Plate 3) Syn. Bryum arcticum var. helveticum (H. Philib.) Husn.

Plants sterile, yellowish green to olive green, up to $3.7 \mathrm{~mm}$ high. Stem unbranched, angular in cross section, with central strand, sclerodermis highly differentiated. Leaves erect appressed to slightly spreading when moist, crowded at stem apex, broadly ovate, \pm orbicular, 1.5 to $1.8 \mathrm{~mm}$ long, 0.6 to $0.7 \mathrm{~mm}$ wide, upper lamina cells vermicular at margin, rhomboidal to hexagonal toward costa, basal lamina cells vermicular to linear at margin, oblong and sun-quadrate toward costa, lamina cells chlorophyllose; margin plane, sometimes serrate towards apex, entire below, bordered (2-3 cells) throughout; costa stout, wider downward, excurrent, superficial cells linear-vermicular above, elongated to oblong below, semicircular in cross section, homogenous.
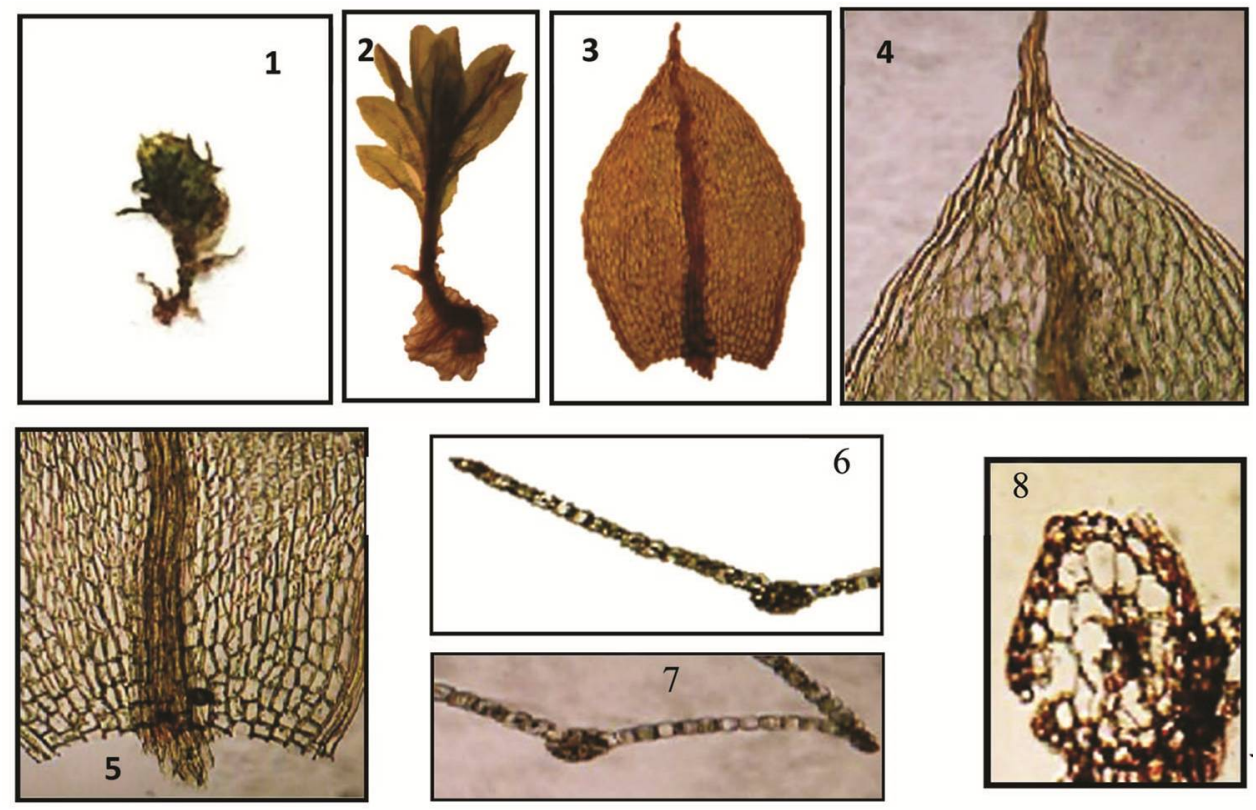

Plate 3. Ptychostomum arcticum (R. Brown) J. R. Spence ex Holyoak \& N. Pederson; 1- Dry plant (X8), 2Fresh plant (X14.5), 3- Leaf (X32), 4- Leaf apex (X147), 5- Leaf base (X135), 6 \& 7- T.S. of leaf (X190, X210), 8- T.S. of stem (X100).

Locality: Aga. Habitat(s): On red brick walls of water basin, exposed to light. Distribution in Egypt: New record. Distribution in Afr1: Egypt only. Distribution in the World: Eur, Am3. Specimens examined: Aga: Nawasat el ghait village, 3.3.2019, Gehad Hamouda, GH 280. (CAIA) 
36. P. capillare (Hedw.) Holyoak \& N. Pederson.

Localities: El-Mansoura, Al-Manzalah. Voucher specimens: GH 295, GH 390. Habitat: On red brick walls of water basin, in semi-shade. Distribution in Egypt: Cai, Dg, Di, S, O. Distribution in Afr1: LBY, CN, ALG, MOR, TUN.Distribution in the World: Afr1, Afr2, As3, As4, As5, Eur, Am1, Am2, Am3, Am4, Am6, Austr1, Austr2, Oc.

37. P. cyclophyllum (Schwägr) J. R. Spence

(Plate 4)

Syn. Bryum cyclophyllum (Schwägr) Bruch \& Schimp; Bryum tortifolium Brid.

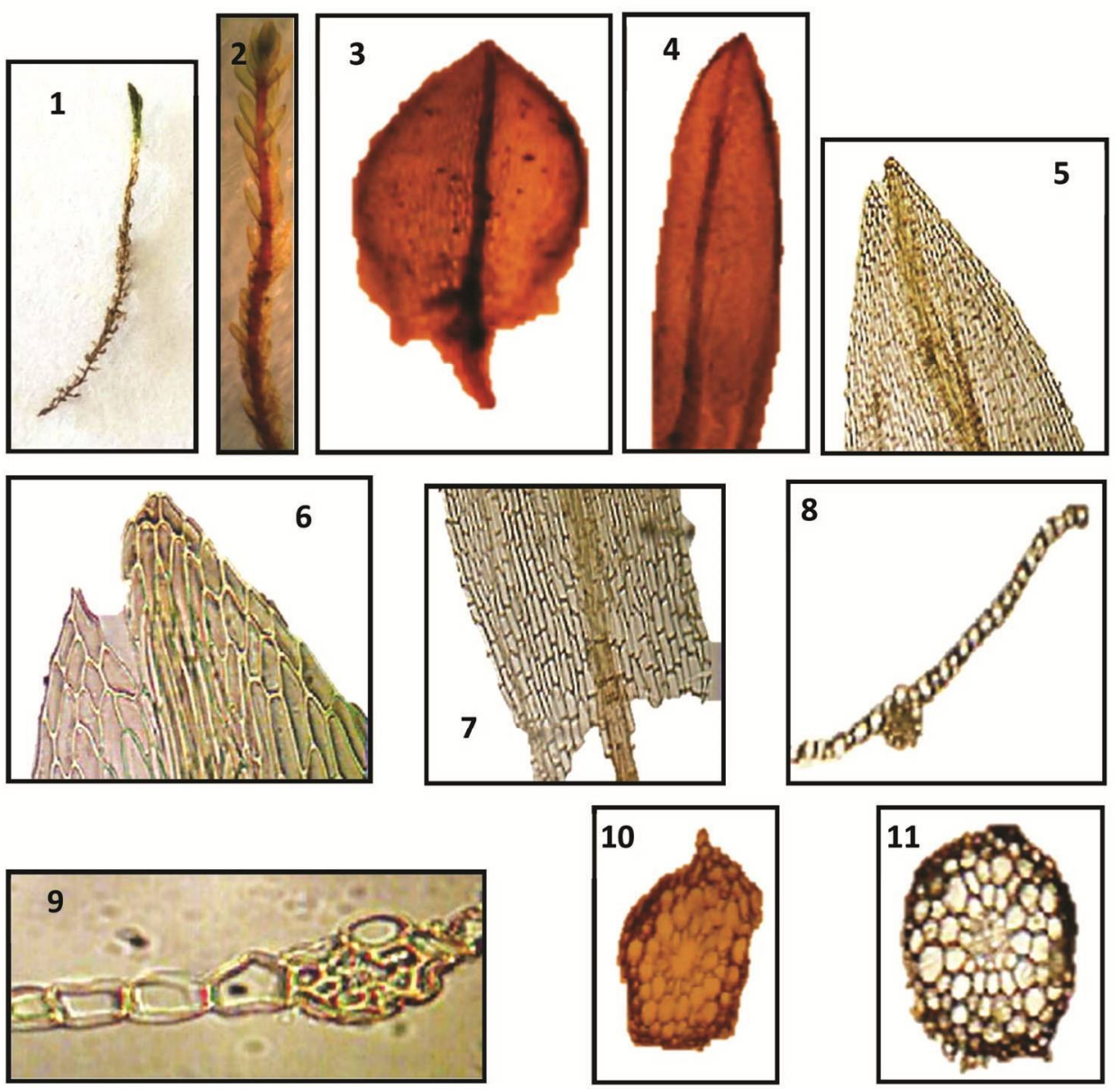

Plate 4. Ptychostomum cyclophyllum (Schwägr) J. R. Spence; 1- Dry plant (X3), 2- Fresh plant (X6), 3 \& 4Leaves (X43, X46), 5- Leaf apex (X107), 6- Upper leaf cells (X215), 7- Basal leaf cells (X115), 8 \& 9 T.S. of leaf (X105, X250), 10 \& 11- T.S. of stem (X117, X125).

Plants sterile, pale green above, yellowish brown below, up to $2 \mathrm{~cm}$ high. Stem unbranched, rounded or angular in cross section, central strand absent, sclerodermis highly differentiated. Leaves tumid when moist, strongly concave, ovate or ligulate, 1 to $1.2 \mathrm{~mm}$ long, $0.60 .7 \mathrm{~mm}$ wide; apex acute; margin plane, entire; costa ending below apex by 1 to 2 cells, superficial 
cells linear, semicircular in cross section, costa homogenous; upper cells rhomboidal and angular, basal cells oblong and rectangular.

Locality: Sherbeen. Habitat: On red brick walls of water basin, exposed to light. Distribution in Egypt: New record. Distribution in Afr1: Egypt only. Distribution in the World: Afr1, Eur, Am3. Specimens examined: Sherbeen: El hataba village, 28.4.2019, Gehad hamouda, GH 322. (CAIA)

Family: Mniaceae

Genus: Pohlia Hedw.

38. P. melanodon (Brid.) A. J. Shaw

Syn. Mniobryum delicatulun (Hedw.) Dixon

Previously recorded, not collected during the present study.

Distribution in Egypt: S. Distribution in Afr1: CN, ALG, MOR, TUN. Distribution in the World: Afr1, Eur, As5.

Family: Bartramiaceae

Genus: Philonotis Brid.

39. P. hastata (Duby) Wijk \& Margad

Locality: Mainiat El-Nasr. Voucher specimens: GH 381, GH 378. Habitat: On red brick walls behind water tap, in shade. Distribution in Egypt: Nf, Cai, Dg, O. Distribution in Afr1: MD. Distribution in the World: Afr1, As1, As2, As3, As5.

\section{Comparison and concluding remarks}

The enumerated bryoflora of the study area, which is a part of Nile delta, is nearly similar to that of Sinai and Cairo, each consists of 22 taxa, than that of the other territories of Egypt (ElSaadawi et al., 2003). Comparison between the enumerated moss elements of the study area and that of Afr1 countries (Ros, et al., 2013) showed that the highest similarity was with Algeria and Morocco, each of which with 28 taxa, and Tunisia with 24 taxa, while the lowest similarity was with Mali, housing two taxa only (El-Saadawi et al., 2013b; Ros et al., 2013).

Similarity between bryoflora of Europe and the study are may be attributed to the northern wind crossing Mediterranean Sea carrying moss propagules from Europe (Zanten and Pòcs, 1981) In this regard, El-Saadawi et al. (2003) mentioned that $81 \%$ of the moss flora of Egypt occur in Europe, while similarity with As5 might be due to the rapprochement in the floristic composition (Ayyad et al., 2000).

The moss species Weissia perligulata, newly recorded for Afr 1 and consequently for Egypt, was supposed to be disjunct element from Am3. Twelve disjunct taxa of briyoflora were recorded earlier in Egypt; six from Mediterranean coast of Egypt (El-Sakaty, 2009; Shabbara, 1990), two from Isthmic Desert (Shabbara, 1999) and four from Nile Delta (Ibrahim, 2006; Taha, 2010). This study shows that the disjunct taxa are now increased to 13. To explain these disjunction, there are some factors like continental drift, the fragmentation of a once more continuous distribution and long-distance dispersal (Schofield and Crum, 1972) and transfer of propagules (within geographical belt) via air currents.

In spite of the recent intensive collection, some taxa, which were recorded 35 years ago by ElSaadawi et al. (1986), were not appeared during this study. This may be rendered to the disappearance of some taxa and new appearance of the others as a natural phenomenon in all living organisms (Okasha, 2010). Recently, this variation was increased by the fast ecological 
changes and long-term impacts of threats, such as changing habitats by urbanization, road construction, changing soil contents and its acidity and air pollution, affecting all biological resources including mosses (Hallingback and Hodgetts, 2000; Taha, 2010).

Sterility does not obstruct the reproduction in all mosses, because many mosses have the ability to reproduce by vegetative fragmentation of gametophyte, which is a very effective mean of propagation. Rarity of fruiting is famous in mosses, as well as, the presence of a single sex is due to limitation of both ecological tolerance and capacity to adapt to environmental change, including that induced by human activity. Rarity of sporophytes in dioecious mosses generally results from spatial separation of male and female plants, often combined with rarity or absence of antheridia, archegonia, or both (Longton and Schuster, 1983). A hypothesis that would explain this rarity is consistent with the low taxonomic diversity and the disjunct, possibly relict, distribution patterns noted among species. Also, early production of asexual propagules was suggested to reduce the immediate selective advantage of producing gametangia and sporophyte (Longton and Miles, 1982). As the spores are unisexual, male and female plants occur only randomly together after dispersal, and sexual reproduction occurs rarely. Therefore, asexually formed propagules functioning ecologically as "spores" and as an effective means of reproduction, play a key role in dispersal ecology and habitat colonization and have a great significance in the dynamic processes of bryophyte communities. In addition, asexual propagules provide possibilities for survival of unfavourable life conditions, and support re-establishment in a habitat after changes in the environmental conditions (Frey and Kürschner, 2011).

NOTE: Afr- Africa (Afr 1- N. Africa, Madeira, Azores, Canary Islands; Afr 2- Central Africa, St. Helena Islands; Afr 3- Madagascar, Mauritius, Reunion Islands; Afr 4- S. Africa, Kergulen Islands), ALGAlgeria, Am- America (Am 1- N. America, Greenland, Allutian Islands, Bermudez; Am 2- Central America; Am 3- West Indian Islands; Am 4- Venezuela, Colombia, Peru, Bolivia, Ecuador, Galapagos Islands; Am 5Brazil, Paraguay, Guinea, Trinidad; Am 6- Chile, Argentina, Urugay, Falkland Islands, Continent of Antarctica), As- Asia (As 1- N. Asia Including Sakhalin; As 2- China, Monogolia, Jaban, Korea, Formosa; As 3- India, Pakistan, Bangladesh, Ceylon, Burma, Siam, Indo-China; As 4- Indonesia, Malaya, Philippine Islands, Newguinea; As 5- Asiatic Part of The Middle East, Including Cyprus), Austr- Australia (Austr 1Australia, Tasmania; Austr 2- New Zezland), Cai- Cairo, CAIA- Ain Shams University Herbarium, CNCanary Islands, Dg- Galala Desert, Di- Isthmic Desert, EGY- Egypt, Eur- Europe, GE- Gebal Elba, LBYLibya, MLI- Mali, Mm- Western Mediterranean Costal Land of Egypt, MOR- Morocco, Nd- Nile Delta, NfNile Fayium, Nn- Nile Nubia, Nv- Nile Vally, O- Oases of the Western Desert, Oc- Pacific Ocean Islands, SSouthern Sinai, TUN- Tunisia.

\section{References}

Ayyad, M.A., Fakhry, A.M. and Moustafa, A.A. 2000. Plant biodiversity in the Saint Catherine area of the Sinai peninsula. Egypt. Biodiversity and Conservation 9: 265-281.

El-Saadawi, W.E., Badawi, A.A. and Refai, M.S. 1986. Mosses of the Nile Delta. Lindbergia 12: 106-110.

El-Saadawi, W.E., Shabbara, H., Abou-Salama, U.Y. and Refai, M.S. 2003. Mosses of different phytogeographical territories of Egypt. Bocconea 16: 133-146.

El-Saadawi, W.E., Abou-Salama, U.Y. and Taha, M.A. 2013a. Mosses of the Egyptian conservation areas: III. Two new Pottiaceae records to Saint Catherine Protected Area and Egypt. Taeckholmia 33: 37-46.

El-Saadawi, W.E., Shabbara, H. and El Sakaty, S. 2013b. Mosses of the Egyptian conservation areas: II. Omyed Protected Area. Cryptogamie. Bryologie 34(1): 1-11.

El-Saadawi, W.E., Shabbara, H., Ibrahim, M. and Taha, M.A. 2015. An Annotated Checklist of Egyptian Mosses. Taeckholmia 35: 1-23.

El-Sakaty, S. 2009. Studies on Bryoflora of Omayed Protected Area. M.Sc. Thesis. Ain Shams University, $350 \mathrm{pp}$. 
El-Sakaty, S., Isaac, H.S., Shabbara H and Aboel-Atta M.A. 2018. Oxystegus (Pottiaceae), a genus new to Bryoflora of Egypt. The Egyptian Journal of Experimental Biology (Botany) 14(1): 117-120.

Flowers, S. 1973. Mosses of Utah and the West of United State. Edited by Arthur Holmgren. Brigham Young University, $567 \mathrm{pp}$.

Frey, W. and Kürschner, H. 2011. Asexual reproduction, habitat colonization and habitat maintenance in bryophytes. Flora 206: 173-184.

Hallingbäck, T. and Hodgetts, N. 2000. Mosses, liverworts and Hornworts. Status Survey and Conservation Action Plan for Bryophytes. Belgian Journal of Botany 134: 95-96.

Hamouda, G.A. 2016. Studies on Bryoflora in Ismailia Province. Msc. Thesis. Botany Department, Faculty of Sciences, Zagazig University, 238 pp.

Hassan, Y.M., Abou-Salama, U.Y., Kamel, W.M. and Eldin, E.M.G. 2017. The Moss Flora of Ismailia Governorate, Egypt with Three New Records. Taeckholmia 36: 30-40.

Ibrahim, M. 2006. Studies on Family Pottiaceae (Music) Qaleabiya Provice, Nile Delta, Egypt. M.Sc. Thesis. Ain Shams University, 194 pp.

Ibrahim, H., Kamel, W., Abou-Salama, U.Y. and Gamal Eldin, E.M. 2013. The moss flora of Saint Katherine Protected Area, South Sinai, with eight new records. Taeckholmia 33: 19-36.

Khalil, M.I. and Farag, M.A. 2018. Additional Pottiaceae Records from Omayed Protected Area, Egypt. The Egyptian Journal of Experimental Biology (Botany) 14(2): 339-345.

Lashin, G.A. 1990. Studies on Bryoflora of Suez Canal Region, Egypt. M.Sc. Thesis. Botany Department, Faculty of Sciences, Zagazig University, $126 \mathrm{pp}$.

Longton, R.E. and Miles, C.J. 1982. Studies on the reproductive biology of mosses. Hattori Botanical Laboratory 52: 219-239.

Longton, R.E. and Schuster, R.M. 1983. Reproductive biology. In: Schuster, R.M. (Ed.). New Manual of Bryoiogy, Vol. 1. Hattori Botanical Laboratory, Nichinan, pp. 386-462.

Mandour, R.A .2013. Drinking Water Toxicity in Health and Diseases. Air water borne diseases 2(1): 7.

Okasha, S. 2010. Altruism researchers must cooperate. Nature 467(7316): 653-655.

Refai, M.S. 1985. Studies on the Bryoflora of the Nile Delta. M.Sc. Thesis. Ain Shams University, 184 pp.

Ros, R.M., Mazimpaka, V., Abou-Salama, U., Aleffi, M., Blockeel, T.L. 2013. Mosses of the Mediterranean, an annotated checklist. Cryptogamie, Bryologie 34(2): 99-283.

Schofield, W.B. and Crum, H.A. 1972. Disjunctions in bryophytes. Annals of the Missouri Botanical Garden 59: $35-43$.

Shabbara, H. 1990. Studies on the bryoflora of the Mediterranean Coast of Egypt. Ph.D. Thesis. Botany Department, Faculty of Science, Ain Shams University, 267 pp.

Shabbara, H. 1999. Three new records of Funariaceae from Egypt. Journal of Bryology 21: 201-205.

Taha, M.A. 2010. Studies on family Pottiaceae (Musci) El-Sharkyia province. M.Sc. Thesis. Ain Shams University, $261 \mathrm{pp}$.

Taha, M.A. 2014. Studies on the bryoflora of some Wadis in Saint Catherine protected area. Ph.D. Thesis. Ain Shams University, $356 \mathrm{pp}$.

Taha, M.A. 2020. Illustration and Description of the Recent Bryaceae Records from Bahariya Oasis-Egypt. Egyptian Journal of Botany 60(2): 575-582.

Wijk, R., Margadant, W.D. and Florschiitz, P.A. 1959-1969. Index Muscorum, Vols. 1-5. Utrecht. International Bureau for Plant Taxonomy and Nomenclature, International Association for Plant Taxonomy, pp. 1-922.

Zanten, B.O. and Pòcs, T. 1981. Distribution and Dispersal of Bryophytes. Advances in Bryology. Germany 1: $479-562$.

(Manuscript received on 23 December, 2020; revised on 12 May, 2021) 